\title{
Effects of Different Levels of Salinity on NKA and NKCC Expression in Asian Sea Bass (Lates calcarifer)
}

\author{
Soheila Saghafiankho ${ }^{1}$, Amir Parviz Salati ${ }^{1, *} \mathbb{B}$, Vahid Morshedi ${ }^{2}$, Ahmad Ghasemi ${ }^{2}$, \\ Mahmood Nafisi Bahabadi²,
}

\author{
${ }^{1}$ Khorramshahr University of Marine Sciences and Technology, Faculty of Marine Natural Resources, Department of \\ Fisheries, Khorramshahr, Iran. \\ ${ }^{2}$ Persian Gulf University, Persian Gulf Research Institute, Bushehr, Iran.
}

\section{Article History}

Received 17 May 2020

Accepted 10 November 2020

First Online 12 November 2020

\section{Corresponding Author}

Tel.: +986153534725

E-mail: apsalati@kmsu.ac.ir

\section{Keywords}

Lates calcarifer

Salinity

Gill

NKCC

NKA

\begin{abstract}
Asian sea bass, Lates calcarifer is one of the most valuable marine fish species that is known to be tolerant to wide range changes of salinity. The species is able to live in freshwater, brackish and marine water, being an ideal model species for studying the effects of salinity on physiological responses. The present study is aimed to evaluate the changes in expression levels of $\mathrm{Na}^{+}-\mathrm{K}^{+}$ATPase (NKA) and $\mathrm{Na}^{+} / \mathrm{K}^{+} / 2 \mathrm{Cl}^{-}$(NKCC) genes in gill tissue of $L$. calcarifer kept in a range of salinities including freshwater ( $0 \mathrm{ppt})$, brackish water (15 ppt) and saline marine water ( 35 and $50 \mathrm{ppt})$. Totals of 180 individuals were randomly distributed into 12 fiberglass tanks (volume $300 \mathrm{~L}$ ) that contained different water salinity variants. After 30 days of experimental captivity, fish were euthanized and gill tissues were collected for NKA and NKCC mRNAs expression analysis. The $U$ shape expression pattern for both NKA and NKCC was recorded. The highest brachial expression was seen in 50 ppt that was statistically different from all other salinity variants. The lowest expression was recorded in 35 ppt. In turns, observed NKA and NKCC expression levels in freshwater were significantly higher than 15 and 35ppt. The current findings showed that the expression levels of major gill transporters, as are NKA and NKCC has the highest expression in unusual conditions, having the lowest expression levels under the most habitual salinity conditions present in the wild environment.
\end{abstract}

\section{Introduction}

Nowadays, the increasing world's human census and changing dietary preferences cause the enlarged demand for aquatic products. As the classic fishery based on the wild-catches has reached its limit the aquaculture is expected to satisfy this demand in the future. Aquaculture is also considered as one of the most economically important branch of agriculture, continuously growing since 1990 and presently exceeding wild-catches (FAO, 2020). On the other hand, survival of many freshwater and marine species in endangered due to the pollution by the inflow of urban wastewater into rivers and seas, the loss of spawning grounds and habitats, the overexploitation by fisheries and inappropriate fishing methods, e.g. trawling (Sarvi et al., 2006). In aquatic organisms, the electrolytebalancing mechanism is of vital importance that enables them to live in changing conditions of the hyper and hypoosmotic environments. The observed variety of osmotic adjustment mechanisms in fish is one of the crucial factors playing role in adaptation to diverse environments (Farshadian et al., 2018; Salati et al., 2011). Adaptation to changes in environmental salinity requires synthesis of specific transport proteins (McCormick, 2001). In fishes many different transporters are involved in osmoregulation, i.e. $\mathrm{Na}^{+}-\mathrm{K}^{+}$ ATPase (NKA), Aquaporins, $\mathrm{H}^{+}$-ATPase, Cystic Fibrosis 
Transmembrane Conductance Regulator (CFTR), $\mathrm{Na}^{+} / \mathrm{H}^{+}$ exchangers (e.g. NHE2 and $\mathrm{NHE3}$ ), $\mathrm{Na}^{+} / \mathrm{Cl}^{-}$cotransporter (NCC) and Na-K-Cl cotransporter (NKCC) (Lin et al., 2006; Yan et al, 2007; Bodinier et al., 2008; Ivanis et al., 2008; Hiroi et al., 2008; Salati et al., 2014). The crucial importance of NKA and NKCC in the osmoregulation mechanism has been previously evidenced by numerous studies (e.g. Patterson et al., 2012).

Asian sea bass, Lates calcarifer is a valuable marine fish known in Australia as Barramundi. The fish is commercially important species for aquaculture in Southeast Asia, being widely farmed in Australia, Thailand and Indonesia (Longbaf Dezfouli et al., 2019). The fish's distribution range extends from the North Indian Ocean to the Western Pacific, covering the areas from Iran to the northern Australia with optimum temperatures range of 28 to $30 \circ \mathrm{C}$ (Tian and Qin, 2003).

L. calcarifer is considered as very attractive species for aquaculture production due to easy use of commercial food, rapid growth rate (the species' growth rate is low in the early stages of life, but rapidly raises when reach $30 \mathrm{~g}$ ) and the high price on the market (Venkatachalam et al., 2018). The species is tolerant to wide span of salinity (0-50 ppt) and water temperature (15-40ㅇ C) that makes it able to live and growth in various environments, such as: the sea, estuaries, coastal wetlands and rivers (Katersky and Carter, 2005; Sorphea et al., 2019). This feature also makes it as a good model species for studying the effects of salinity on physiological process. If the saltwater or brackish water could be used for rearing economically valuable fish, animal protein deficiency can be largely offset (Harpaz et al., 2005; Nafisi Bahabadi, 2016).

Numerous studies on fish physiological responses to salinity changes that have been extensively carried out in diverse fish species showed benefits of choosing the optimal salinity for species which can spend more energy on growth (Salati et al., 2011; Salati et al., 2014; Farshadian et al., 2018). This especially concerns the species that could be cultured in a wide range of salinities, such as $L$. calcarifer, which can directly lead to increased production efficiency. Therefore, by studying the expression of the NKA and NKCC genes, a better understanding of the $L$. calcarifer response to the changes in environmental salinity and optimal salinity for its culture can be achieved.

\section{Material and Methods}

\section{Experimental Design}

One hundred and eighty $(n=180)$ specimens of $L$. calcarifer with a mean initial weight of $34.36 \pm 0.41 \mathrm{~g}$ were purchased and transferred to the laboratory rearing system. The fish were kept in 12 fiberglass circular tanks of volume $300 \mathrm{~L}$ (15 fish per tank) for 2 weeks in 50 ppt salinity for acclimation to experimental conditions. During this time, the fish were hand-fed ad libitum, two times daily at 08:00 and 16:00 (Havoorrash, Iran). Four salinity variants were used, namely: 0, 15, 35 and $50 \mathrm{ppt}(\mathrm{g} / \mathrm{L})$ under the current study. After adaptation period, the water salinity was gradually decreased to the desired salinity over a period of 7 days. For this tap water was used to decrease water salinity in experimental groups, excluding already available salinity of 50 ppt. In 0 ppt group Persian Gulf water (50 ppt) was fully replaced by freshwater. Afterwards the fish was kept for 30 days in the obtained salinity. The salinity of the water was monitored daily by the portable meters (WTW Model U10) and 50\% of the tank water was replaced daily to maintain its quality. Subsequently, fish were euthanized and gill tissues were collected for further genetic analyses.

\section{RNA Extraction}

Primer sequences for NKA and NKCC genes were designed based on genetic information available in NCBI gene bank database based on the records assigned to the accession numbers: XM_018661006.1 and XM_018701955.1. For this purpose, Primer 3 software (ver. 0.4.0) was used. The resulted primer sequences are shown in Table 1. Total RNAs were extracted from gill tissues using the RNA extraction kit (Roche). The RNA concentration was measured by spectrophotometry and its quality was assessed by $1 \%$ agarose electrophoresis. Next, the isolated RNA was used to synthetize of cDNA using M-MLV Reverse Transcriptase (Ferments). The resulted CDNA was used as template for further PCR amplification that was performed under the following conditions: denaturation at $94^{\circ} \mathrm{C}$ for $5 \mathrm{~min}$, followed by 30 cycles of $94^{\circ} \mathrm{C}$ for $60 \mathrm{~s}, 58^{\circ} \mathrm{C}$ for $45 \mathrm{~s}$, and $72^{\circ} \mathrm{C}$ for 1 $\mathrm{min}$, with a final extension step of $72^{\circ} \mathrm{C}$ for $10 \mathrm{~min}$. The

Table 1. Primer sequences used for cloning and qPCR

\begin{tabular}{lccc}
\hline Primer name & Primer sequence (from 5 to 3) & Temperature $\left({ }^{\circ} \mathrm{C}\right)$ \\
\hline NKA & F: CTCAGATGGCCAGGCAAAGA & 60 & 60 \\
\hline NKCC & R: GGGCCAGGATCTCTTTTGCT & 60 & 60 \\
\hline EF-l $\alpha$ & F: TGGTCAGGCTGGGATTGTTC & 60 \\
\hline & R: GGGCCCAGACTCCTTGAAAT & 60 \\
\hline
\end{tabular}


PCR products were separated on a $1 \%$ agarose gel and then purged by PCR purification kit (Qiagene). In order to validate the correctness of target genes the obtained fragments DNA was sent for sequencing by the outsource company (Tops gene).

\section{Gene Expression Studies}

Real-time PCR analysis was carried out by application of designed primers for NKA and NKCC genes. The elongation factor 1 -alpha $(e f 1-\alpha)$ was chosen as internal control for qRT-PCR because it was proven to characterize by stable expression across different tissues (Paria et al., 2016). The summary of primer sequences used for qRT-PCR is shown in Table 1. Gill tissues were homogenized by liquid nitrogen, and total RNA was isolated using RNA extraction kit (Sinagen) according to the manufacturer' protocol. RNA samples quality was checked using a NanoDrop ND-1000 spectrophotometer. The cDNA was synthesized from
$1 \mu \mathrm{g}$ of total RNA using a RevertAidTM First Strand cDNA Synthesis Kit (Fermentas, K1622). The obtained cDNA were used to perform quantitative real-time PCR, where ef1- $\alpha$ gene was used as reference gene in all analyses. The real-time PCR was performed with the SYBR Green Real-time PCR Master Mix (Sinagene, Iran) in a RotorGen3000 real-time PCR detection system (Corbett research). Each reaction was carried out in a total volume of $20 \mu \mathrm{L}$ consisting $10 \mu \mathrm{L}$ SYBR Green Real-time PCR Master Mix (Sinagene), $10 \mathrm{pmol}$ of each primer, $1 \mu \mathrm{l}$ of cDNA template and nuclease free water in amount required to fill the reaction volume. The aliquots were run with the following thermal cycling program: an initial activation step at $94^{\circ} \mathrm{C}$ for $2 \mathrm{~min}$ and then 40 cycles of $94^{\circ} \mathrm{C}$ for $15 \mathrm{~s}, 60^{\circ} \mathrm{C}$ for $30 \mathrm{~s}$ and $72^{\circ} \mathrm{C}$ for $30 \mathrm{~s}$. All real-time PCRs were performed in triplicates. Melt curve analysis was performed on the PCR products at the end of each run to ensure that a single product was amplified. Relative targeted gene expression was calculated for each reaction by the $\Delta \Delta \mathrm{Ct}$ method.

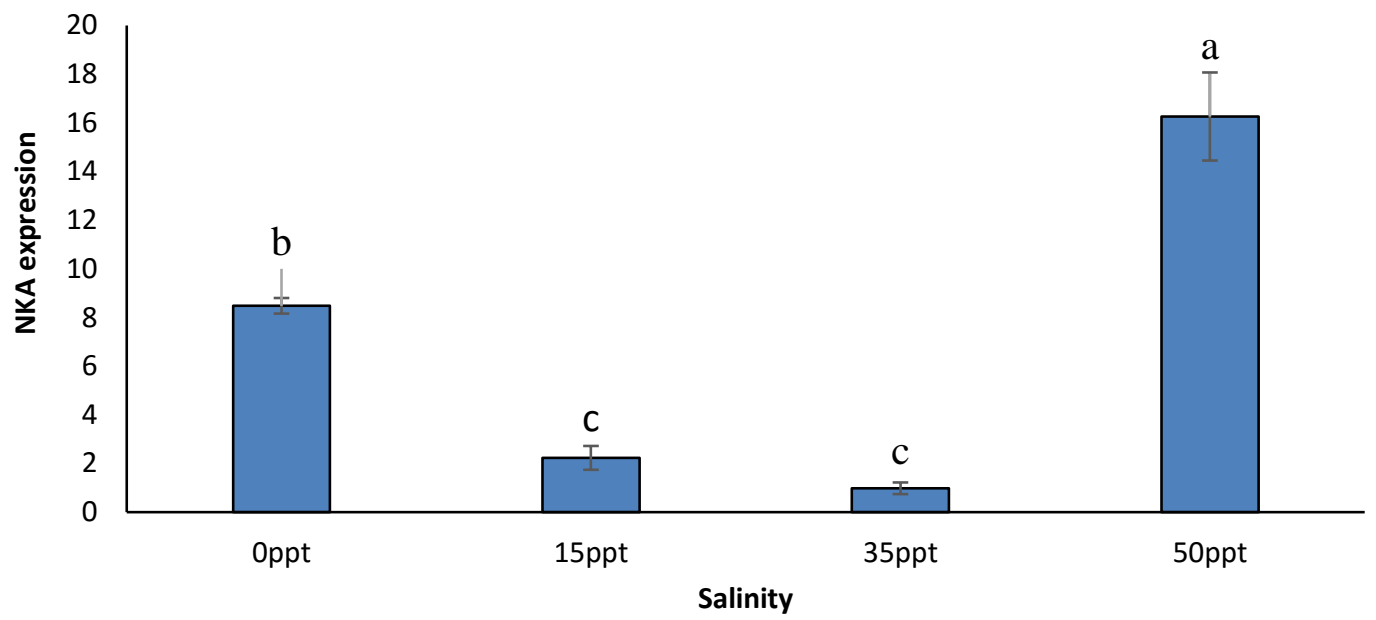

Figure 1. The expression pattern of NKA gene in gill tissues of Asian sea bass (Lates calcarifer) under the different levels of salinity. The letters $a, b$ and $c$ indicate a statistically significant different results groups $(P<0.05)$.

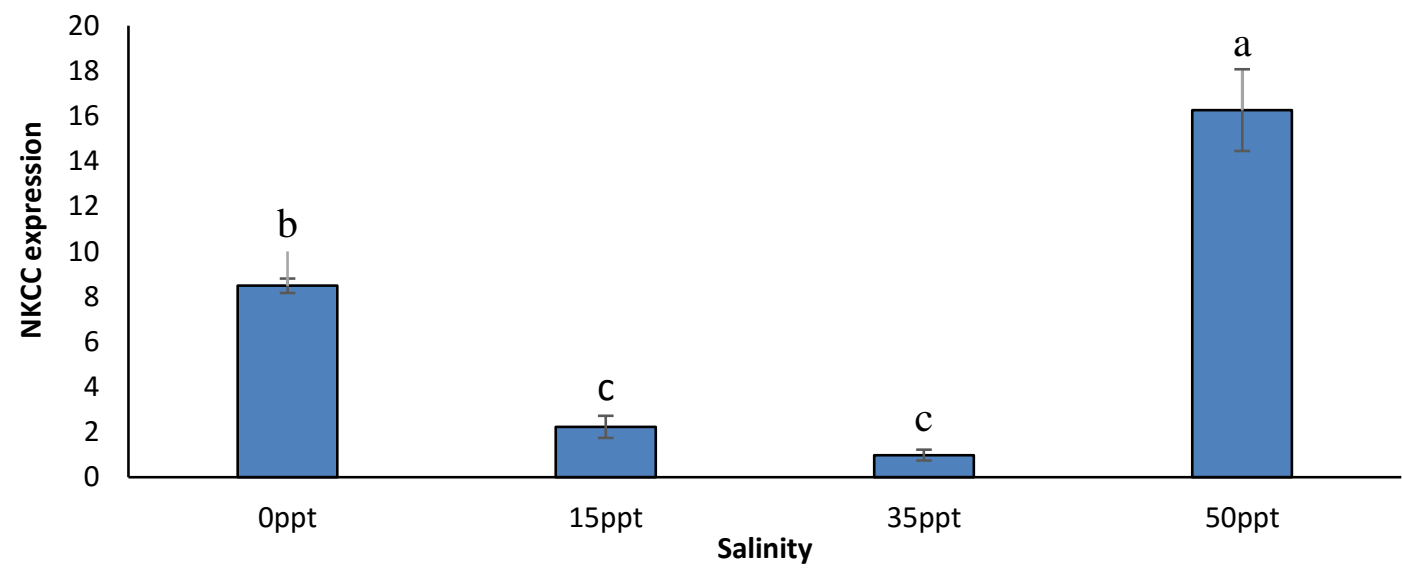

Figure 2. The expression pattern of NKCC gene in gill tissues of Asian sea bass (Lates calcarifer) under the different levels of salinity. The letters $a, b$ and $c$ indicate a statistically significant different results groups $(P<0.05)$. 


\section{Statistical Analysis}

All data were presented as mean \pm standard deviation. The observed differences in the analysis results were tested for significance using a one-way analysis of variance (ANOVA) and the Duncan's post hoc $(P<0.05)$.

\section{Results}

No mortality was recorded during the experimental captive of fish under determined salinity variants. The PCR amplification product length of the NKA and NKCC genes were 200 and 150, respectively. The results of NKA and NKCC genes expression analysis in gill tissues of fish exposed to different salinity conditions are shown in the Figures 1 and 2 . Both genes displayed specific U-like shape expression pattern. The expression levels of NKA and NKCC in the $50 \mathrm{ppt}$ condition were the highest, being significantly different from other variants $(P<0.05)$. The expression of NKA and $N K C C$ in freshwater (0 ppt) treatment was significantly higher than in $15 \mathrm{ppt}$ and $35 \mathrm{ppt}$ variants but statistically lower than treatment of $50 \mathrm{ppt}$. There was no significant difference between 15 ppt and 35 ppt treatments.

\section{Discussion}

Most of the teleost species are stenohaline that live exclusively in freshwater or saltwater. The others are euryhaline that have the ability to withstand wide changes in environmental salinity (Evans, 1984). The euryhalinity is considered as one of the most important feature that enables the teleost fishes to colonize all aquatic habitats, taking important part in the development of anadromy and catadromy life styles. Adaptation to different environmental salinity stimulates changes and/or activation of ion specific transport mechanisms that can be observed in euryhaline species. Due to their enzymatic properties, gill mitochondrion-rich (MR) cells are considered to be the major site of osmotic regulation in teleosts (Lin et al., 2004a; Lin et al., 2003; Evans et al., 2005).

Euryhaline species show adaptive changes in gill NKA genes activity following salinity changes. The majority of energy spent during osmotic regulation is devoted to the synthesis of ion transporting proteins and the active maintenance of the electrochemical gradient by NKA proteins (Hwang and Lee, 2007). According to the current model of ions secretion in gills of saltwater species, the driving force for chloride secretion is the electrochemical gradient generated by NKA proteins. Sodium secretion occurs through the specific cellular pathway of cations in the direction of their electrochemical gradient (Marshall, 2002).

Despite the NKA genes response to environmental changes of salinity is variable in euryhaline fish, two main patterns can be discerned that enable to interpret observed changes: (1) the directly proportional association that characterizes anadromous fish and is based on mechanism where increased salinity induces greater NKA genes expression as well as protein activity (McCormick, 1995, 2001; Tipsmark et al., 2002; Tang and Lee, 2007) and (2) the U-shaped relationship described in some euryhaline species (Jensen et al. 1998). According to the first expression pattern it can expect higher levels of NKA genes expression and greater proteins activity in marine fish group with comparison to the brackish and freshwater ones. Indeed, Tang and Lee (2007) reported that the expression of NKA in gills of a euryhaline teleost fish pufferfish (Tetraodon nigroviridis) was higher in the marine group than in the freshwater group. The U-shaped NKA response pattern mechanism to salinity changes creates potential for improvement of the available energy consumption by its reduction for purposes of osmoregulation and redirecting for other processes.

$N K A$ gene expression in gills of $L$. calcarifer was lower in salinity of $35 \mathrm{ppt}$ in comparison to other experimental variants and increased both under decreased and increased salinity conditions $(P<0.05)$. Similar results on NKA genes activity in gill tissues was reported by Saoud et al. (2007) for marbled spinefoot (Siganus rivulatus) kept in 25, 30, 35 and 40 ppt salinity for 6 weeks where the lowest NKA expression level was recorded in fish reared in salinity of 35 ppt. Another example of U-like mRNA expression pattern of $N K A \alpha 1 b$ subunit was reported in so-iuy mullet (Liza haematocheilus), where the significant increment of gene expression level was observed 5 days after transferring fishes to salinities of 2, 14 and 42 ppt and retaining its lowest expression in control group kept in 28 ppt salinity (Shen et al., 2015). This U-like response pattern in NKA expression activity to the changes in environmental salinity was also recorded for such species as: Common carp (Cyprinus carpio) (Salati et al., 2011), Dorada (Sparus aurata) (Laiz-Carrión et al., 2005) and pufferfish (Tetraodon nigroviridis) (Lin et al., 2004b). In general, it can conclude that the lowest level of NKA gill expression is observed for conditions that are observed in natural habitats of studied fish, which reflects the species' evolutionary-based genetic adaptation to specific environments (Kang et al., 2008).

A link between NKA and NKCC expression during osmoregulation process by gill's mitochondrion-rich (MR) cells had been reported in some previous studies (Tipsmark et al., 2002; Shirangi et al., 2017). In the current study, the lowest expression of NKCC was observed in salinity of $35 \mathrm{ppt}$ and with both positive and negative salinity changes, the expression of this gene increased in gill tissue. Similarly, to NKA its expression in 50 ppt treatment was significantly higher compared to other treatments. In euryhaline bony fish, gills usually secrete extra chlorine to maintain a constant plasma chlorine concentration in environments of different salinity (Evans et al., 2005). In the chlorine secretion model of MR cells in gill tissues, NKCC is expressed in the basolateral membrane to transfer chlorine from the 
blood stream to MR cells that is especially important mechanism in hyperosmotic conditions of marine environment (Marshall, 2002; Evans et al., 2005). Higher expression of NKCC1a was also observed in gills of Indian ricefish (Oryzias dancena) from sea and brackish waters when compared to freshwater fish (Kang et al., 2010). The increase in the expression level of NKCC1a in MR cells of the gill tissues can suggest the higher efficacy of chlorine transfer from the plasma in $O$. dancena that inhabits brackish water, which evidences the adaptation to hypersomatic environment (Kang et al., 2010). It is also reported that freshwater residing $O$. latipes shows better hypoosmoregulatory ability, while $O$. dancena residing of brackish water characterizes by higher hyperosmoregulatory adaptation abilities (Kang et al., 2008).

In the study of Breves et al. (2010) on Mozambique (Oreochromis mossambicus) and Nile tilapia (Oreochromis niloticus) acclimated to brackish water and freshwater, after transfer to seawater, the expression of NKCC in gill increased in O. mossambicus and decreased in $O$. niloticus. It may be due to the reduced ability of $O$. niloticus' gill to excrete the excess of ions in a hyperosmotic environment and the limited capacity to increase of NKCC expression needed for adaptation to saline environment. The pattern of increment in NKCC expression levels in relation to increased salinity in $O$. mossambicus is consistent with the results in present study.

Shirangi et al. (2017) studied the expression of NKA and NKCC genes during short-term salinity transfer in Persian sturgeon (Acipenser persicus) and found that NKA and NKCC genes expression in the gills increased after transfer to brackish waters of the Caspian Sea. They suggested that the increased activity of NKCC during salt excretion in the Caspian Sea water can lead to sodium penetration into the chloride cells and; therefore, increasing NKA activity that tends to maintain intracellular sodium homeostasis.

In striped bass (Morone saxatilis), transfer from freshwater to seawater increased NKA and NKCC expression levels in gills after 3 days. Conversely, the transfer from seawater to freshwater decreased NKCC expression level in the species after 24 hours (Tipsmark et al., 2004). In turns, under 15 ppt salinity that is specific for brackish water, the NKA activity in the species was stimulated by transfer to either freshwater or seawater conditions, suggesting both a hyper and a hypoosmoregulatory response of the gene expression (Tipsmark et al., 2004).

\section{Conclusion}

It could be stated that the effect of different salinities on the expression of NKA and NKCC genes in gill tissues of $L$. calcarifer showed the lowest expression levels in the salinity conditions (15-35 ppt) that matches to the species' natural habitat. Moreover, increased levels of NKA and NKCC gene expression were observed in higher and lower salinities. Despite the species' ability to survive in wide salinity levels environments, the salinity variant of $35 \mathrm{ppt}$ requires the least energy consumption needed for osmoregulation and thus some extra dynamism is available for fish metabolic activities, such as growth.

\section{Highlights}

NKA and NKCC expression showed $U$ pattern in response to different environmental salinities in gill of Lates calcarifer

Lowest expression of studied genes was seen in 35 ppt in gill of Lates calcarifer

Highest expression of examined genes was seen in $50 \mathrm{ppt}$ in gill of Lates calcarifer

\section{Acknowledge}

We would like to thank Khorramshahr University of Marine Science and Technology for supporting this work under Research Grant No. 163.

\section{References}

Bodinier, C., Boulo, V., Lorin-Nebel, C., \& Charmantier, G. (2008). Influence of salinity on the localization and expression of the CFTR chloride channel in the ionocytes of the European sea-bass Dicentrarchus labrax during ontogeny. FASEB Journal, 22, 933.2. https://doi.org/10.1096/fasebj.22.1

Breves, J., Hasegawa, S., Yoshioka, M., Fox, B., Davis, L., Lerner, D., \& Grau, E. (2010). Acute salinity challenges in Mozambique and Nile tilapia: differential responses of plasma prolactin, growth hormone and branchial expression of ion transporters. General and Comparative Endocrinology, 167(1), 135-142.

https://doi.org/10.1016/j.ygcen.2010.01.022

Paria, A., Dong, J., Babu, P.P., Makesh, M., Chaudhari, A., Thirunavukkarasu, A.R., Purushothaman, C.S., \& Rajendran, K.V. (2016). Evaluation of candidate reference genes for quantitative expression studies in Asian seabass (Lates calcarifer) during ontogenesis and in tissues of healthy and infected fishes. Indian Journal of Experimental Biology, 54(9), 597-605.

Evans, D.H. (1984). The Roles of Gill Permeability and Transport Mechanisms. In W. S. Hoar \& D. J. Randall (Eds.), Fish Physiology (pp. 239-283). Academic Press.

Evans, D.H., Piermarini, P.M., \& Choe, K.P. (2005). The Multifunctional Fish Gill: Dominant Site of Gas Exchange, Osmoregulation, Acid-Base Regulation, and Excretion of Nitrogenous Waste. Physiological Reviews, 85(1), 97177. https://doi.org/10.1152/physrev.00050.2003

FAO (2020). Food and Agriculture Organization of the United Nations http://www.fao.org/. Accessed 01 September 2020.

Farshadian, R., Salati, A.P., Keyvanshokooh, S., \& PashaZanoosi, H. (2018). Physiological responses of Yellowfin seabream (Acanthopagrus latus) to acute salinity challenge. Marine and Freshwater Behaviour and Physiology, 51(5), 313-325.

https://doi.org/10.1080/10236244.2019.1573638 
Harpaz, S., Hakim, Y., Slosman, T., \& Eroldogan, O.T. (2005). Effects of adding salt to the diet of Asian sea bass Lates calcarifer reared in fresh or salt water recirculating tanks, on growth and brush border enzyme activity. Aquaculture, 248(1), 315-324.

https://doi.org/10.1016/j.aquaculture.2005.03.007

Hiroi, J., Yasumsu, S., McCormick, S.D., Hwang, P.-P., \& Kaneko, T. (2008). Evidence for an apical $\mathrm{Na}-\mathrm{Cl}$ cotransporter involved in ion uptake in a teleost fish. Journal of Experimental Biology, 211, 2584-2599. https://doi.org/10.1242/jeb.018663

Hwang, P.-P., \& Lee, T.-H. (2007). New insights into fish ion regulation and mitochondrion-rich cells. Comparative Biochemistry and Physiology Part A: Molecular \& Integrative Physiology, 148(3), 479-497. https://doi.org/10.1016/j.cbpa.2007.06.416

Ivanis, G., Esbaugh, A.J., \& Perry, S.F. (2008). Branchial expression of localization of SLC9A2 and SLC9A3 sodium/hydrogen exchangers and their possible role in acid-base regulation in freshwater rainbow trout (Oncorhynchus mykiss). Journal of Experimental Biology, 211, 2467-2477. https://doi.org/10.1242/jeb.017491

Jensen, M.K., Madsen, S.S., \& Kristiansen, K. (1998). Osmoregulation and salinity effects on the expression and activity of $\mathrm{Na}+, \mathrm{K}+-\mathrm{ATPase}$ in the gills of European sea bass, Dicentrarchus labrax (L.). Journal of Experimental Zoology, 282(3), 290-300.

https://doi.org/10.1002/(sici)1097-

010x(19981015)282:3<290::Aid-jez2>3.0.Co;2-h

Kang, C.-K., Tsai, H.-J., Liu, C.-C., Lee, T.-H., \& Hwang, P.-P. (2010). Salinity-dependent expression of a $\mathrm{Na}+, \mathrm{K}+, 2 \mathrm{Cl}-$ cotransporter in gills of the brackish medaka Oryzias dancena: a molecular correlate for hyposmoregulatory endurance. Comparative Biochemistry and Physiology Part A: Molecular \& Integrative Physiology, 157(1), 7-18. https://doi.org/10.1016/j.cbpa.2010.05.013

Kang, C.-K., Tsai, S.-C., Lee, T.-H., \& Hwang, P.-P. (2008). Differential expression of branchial $\mathrm{Na}+/ \mathrm{K}+$-ATPase of two medaka species, Oryzias latipes and Oryzias dancena, with different salinity tolerances acclimated to fresh water, brackish water and seawater. Comparative Biochemistry and Physiology Part A: Molecular \& Integrative Physiology, 151(4), 566-575. https://doi.org/10.1016/j.cbpa.2008.07.020

Katersky, R.S., \& Carter, C.G. (2005). Growth efficiency of juvenile barramundi, Lates calcarifer, at high temperatures. Aquaculture, 250(3-4), 775-780. https://doi.org/10.1016/j.aquaculture.2005.05.008

Laiz-Carrión, R., Sangiao-Alvarellos, S., Guzmán, J.M., Martín del Río, M.P., Soengas, J.L., \& Mancera, J.M. (2005). Growth performance of gilthead sea bream Sparus aurata in different osmotic conditions: Implications for osmoregulation and energy metabolism. Aquaculture, 250(3), 849-861.

https://doi.org/10.1016/j.aquaculture.2005.05.021

Lin, L.Y., Horng, J.L., Kunkel, J.G., \& Hwang, P.P. (2006). Proton pump-rich cell secretes acid in skin of zebrafish larvae. American Journal of Physiology Cell Physiology, 290, 371-378. https://doi.org/10.1152/ajpcell.00281.2005

Lin, C.-H., Huang, C.-L., Yang, C.-H., Lee, T.-H., \& Hwang, P.-P. (2004a). Time-course changes in the expression of $\mathrm{Na}$, KATPase and the morphometry of mitochondrion-rich cells in gills of euryhaline tilapia (Oreochromis mossambicus) during freshwater acclimation. Journal of
Experimental Zoology Part A: Comparative Experimental Biology, 301A (1), 85-96.

https://doi.org/10.1002/jez.a.20007

Lin, C.H., Tsai, R.S., \& Lee, T.H. (2004b). Expression and distribution of $\mathrm{Na}$, K-ATPase in gill and kidney of the spotted green pufferfish, Tetraodon nigroviridis, in response to salinity challenge. Comparative Biochemistry and Physiology Part A: Molecular \& Integrative Physiology, 138(3), 287-295. https://doi.org/10.1016/j.cbpb.2004.04.005

Lin, Y.M., Chen, C.N., \& Lee, T.H. (2003). The expression of gill $\mathrm{Na}, \mathrm{K}-\mathrm{ATPase}$ in milkfish, Chanos chanos, acclimated to seawater, brackish water and fresh water. Comparative Biochemistry and Physiology Part A: Molecular \& Integrative Physiology, 135(3), 489-497. https://doi.org/10.1016/S1095-6433(03)00136-3

Longbaf Dezfouli, M., Ghaedtaheri, A., Keyvanshokooh, S., Salati, A.P., Mousavi, S.M., \& Pasha-Zanoosi, H. (2019). Combined or individual effects of dietary magnesium and selenium nanoparticles on growth performance, immunity, blood biochemistry and antioxidant status of Asian seabass (Lates calcarifer) reared in freshwater. Aquaculture Nutrition, 25(6), 1422-1430. https://doi.org/10.1111/anu.12962

Marshall, W.S. (2002). $\mathrm{Na}^{+}, \mathrm{Cl}^{-}, \mathrm{Ca}^{2+}$ and $\mathrm{Zn}^{2+}$ transport by fish gills: retrospective review and prospective synthesis. Journal of Experimental Zoology, 293(3), 264-283. https://doi.org/10.1002/jez.10127

McCormick, S.D. (2001). Endocrine control of osmoregulation in Teleost fish. American Zoologist, 41: 781-794. https://doi.org/10.1093/icb/41.4.781

McCormick, S.D. (1995). Hormonal Control of Gill $\mathrm{Na}^{+}, \mathrm{K}^{+}$ ATPase and Chloride Cell Function. In C. M. Wood \& T. J. Shuttleworth (Eds.), Fish Physiology (pp. 285-315). Academic Press.

Nafisi Bahabadi, M. (2016). The effects of different levels of water salinity on growth, feeding performance, body composition and physiological responses in Asian sea bass (Lates calcarifer). Fisheries Science and Technology, 5(2), 99-112

Patterson, J., Bodinier, C., \& Green C. (2012). Effects of low salinity media on growth, condition, and gill ion transporter expression in juvenile Gulf killifish, Fundulus grandis. Comparative Biochemistry and Physiology Part A: Molecular \& Integrative Physiology, 161, 415-421. https://doi.org/10.1016/j.cbpa.2011.12.019

Salati, A.P., Baghbanzadeh, A., Soltani, M., Peyghan, R., \& Riazi, G. (2011). Effect of different levels of salinity on gill and kidney function in common carp Cyprinus carpio (Pisces: Cyprinidae). Italian Journal of Zoology, 78(3), 298-303. https://doi.org/10.1080/11250003.2011.567400

Salati, A.P., Ferrando, S., Movahedinia, A., Gambardella, C., \& Gallus, L. (2014). Effect of different levels of salinity on immunolocalization of $\mathrm{Na}^{+}-\mathrm{K}^{+}$ATPase and Aquaporin 3 in kidney of common carp Cyprinus carpio. Iranian Journal of Veterinary Research, 15(1), 45-49. https://doi.org/10.22099/ijvr.2014.1981

Saoud, I.P., Kreydiyyeh, S., Chalfoun, A., \& Fakih, M. (2007). Influence of salinity on survival, growth, plasma osmolality and gill $\mathrm{Na+-K+-ATPase}$ activity in the rabbitfish Siganus rivulatus. Journal of Experimental Marine Biology and Ecology, 348(1), 183-190. https://doi.org/10.1016/j.jembe.2007.05.005

Sarvi, K., Niksirat, H., Mojazi Amiri, B., Mirtorabi, S.M., Rafiee, G.R, \& Bakhtiyari, M. (2006). Cryopreservation of semen 
from the endangered Caspian brown trout (Salmo trutta caspius). Aquaculture, 256(1), 564-569. https://doi.org/10.1016/j.aquaculture.2006.02.012

Shen, A., Jiang, K., Wang, J., \& Shen, X. (2015). Effects of Salinity on Growth, Feeding and the mRNA Expression of $\mathrm{Na}+/ \mathrm{K}+-A T P a s e$ and HSP90 in Liza haematocheila. Environment and Ecology Research, 3(3), 51-59. https://doi.org/10.13189/eer.2015.030301

Shirangi, S.A., Kalbassi, M.R., Khodabandeh, S., Jafarian, H., \& Lignot, J.H. (2017). Immunolocalization of $\mathrm{Na}^{+} / \mathrm{K}^{+}$ ATPase, $\mathrm{Na}^{+} / \mathrm{K}^{+} / 2 \mathrm{Cl}^{-}$co-transporter (NKCC) and mRNA expression of $\mathrm{Na}^{+} / \mathrm{K}^{+}$-ATPase $\alpha$-subunit during shortterm salinity transfer in the gills of Persian sturgeon (Acipenser persicus, Borodin, 1897) juveniles. Journal of Applied Ichthyology, 33(3), 347-353. https://doi.org/10.1111/jai.13260

Sorphea, S., Terai, A., Sreyrum, P., Lundh, T., Barnes, A.C., Da, C.T., \& Kiessling, A. (2019). Growth performance of fry and fingerling Asian Seabass (Lates calcarifer) from Cambodian brood stock reared at different salinities. Livestock Research for Rural Development, 31(3).

Tang, C., \& Lee, T. (2007). The effect of environmental salinity on the protein expression of $\mathrm{Na}+\mathrm{K}+-\mathrm{ATPase}$, $\mathrm{Na}^{+} / \mathrm{K}^{+} / 2 \mathrm{Cl}^{-}$cotransporter, cystic fibrosis transmembrane conductance regulator, anion exchanger 1, and chloride channel 3 in gills of a euryhaline teleost, Tetraodon nigroviridis. Comparative Biochemistry and Physiology Part A: Molecular \& Integrative Physiology, 147(2), 521-528. https://doi.org/10.1016/j.cbpa.2007.01.679

Tian, X., \& Qin, J.G. (2003). A single phase of food deprivation provoked compensatory growth in barramundi Lates calcarifer. Aquaculture, 224(1), 169-179. https://doi.org/10.1016/S0044-8486(03)00224-2

Tipsmark, C.K., Madsen, S.S., \& Borski, R.J. (2004). Effect of salinity on expression of branchial ion transporters in striped bass (Morone saxatilis). Journal of Experimental Zoology Part A: Comparative Experimental Biology, 301(12), 979-991. https://doi.org/10.1002/jez.a.119

Tipsmark, C.K., Madsen, S.S., Seidelin, M., Christensen, A.S., Cutler, C.P., \& Cramb, G. (2002). Dynamics of $\mathrm{Na}^{+}, \mathrm{K}^{+}, 2 \mathrm{Cl}^{-}$ cotransporter and $\mathrm{Na}^{+}, \mathrm{K}^{+}$-ATPase expression in the branchial epithelium of brown trout (Salmo trutta) and atlantic salmon (Salmo salar). Journal of Experimental Zoology, 293(2), 106-118. https://doi.org/10.1002/jez.10118

Venkatachalam, S., Kandasamy, K., Krishnamoorthy, I., \& Narayanasamy, R. (2018). Survival and growth of fish (Lates calcarifer) under integrated mangroveaquaculture and open-aquaculture systems. Aquaculture Reports, 9, 18-24. https://doi.org/10.1016/j.aqrep.2017.11.004

Yan, J.J., Chou, M.Y., Kaneko, T., \& Hwang, P.P. (2007). Gene expression of $\mathrm{Na}^{+} / \mathrm{H}^{+}$exchanger in zebrafish $\mathrm{H}^{+}$-ATPaserich cells during acclimation to low- $\mathrm{Na}^{+}$and acidic environments. Amerian Journal of Physiology Cell Physiology, 293, 1814-1823.

https://10.1152/ajpcell.00358.2007 